JOURNAL OF SECURITY AND SUSTAINABILITY ISSUES ISSN 2029-7017 print/ISSN 2029-7025 online 2019 June Volume 8 Number 4 http://doi.org/10.9770/jssi.2019.8.4(19)

\title{
Scopus
}

\section{A POTENTIAL INFLUENCE OF TAX INEQUALITY ON THE SUSTAINABLE PUBLIC MANAGEMENT}

\author{
Gediminas Dubauskas
}

General Jonas Žemaitis Military Academy of Lithuania, Šilo st. 5a, Vilnius, LT-10322, Lithuania

E-mail: gediminas.dubauskas@lka.lt

Received 15 January 2019; accepted 13 May 2019; published 30 June 2019

\begin{abstract}
The sustainability of national finances is certainly an important issue for a country's development. These aggregate perceptions change the public sector of the nation and the safety of citizens' lives. Therefore, a significant focus on broadly improving financial research can be a significant issue. In addition, this activity may be organized in connection with applicable higher education programs. On the other hand, the understanding of financial management of governments in different countries are treated differently. This is becoming an increasingly important condition that broadly discussion does not directly benefit the overall development of financial education in recent years. One of the possible ways to deal with personal finances in various economic conditions may be a change in the attitude towards knowledge financing among top management in universities. Young people can be supported by financial education programs that are clearly included in their underground or postgraduate courses. A proper management of education programs can help improve student learning experiences and economic well-being. In addition, training based on transparent public administration reliably fosters patriots of the country and people's intolerance for non-transparent activities of public servants. Another important task of the paper is to show how the management of public debt and government spending can affect the sustainability of fiscal policy. In addition, this document also attempts to clarify questions about the economic importance of financial education at all levels of education. This concept of tax burden can encourage every citizen to be responsible for the activities of government employees and for the transparency of the budget planning process. Improving government revenues is indeed a complicated procedure. Because the same concept of taxes is used as in fixed costs for the public sector, when a person does not directly receive anything but additional payments for most public sector services. Thus, the confusion of economical terms is fairly constant, that again demonstrates a need for public finance literacy in all finance areas. Definitely it is a serious programme for scientists. One of the problems is regarding a realization of the country's tax burden. The official average tax burden is usually more than thirty percent from the Lithuania's nominal gross domestic product in recent years. On the other hand an average tax burden for a private person is usually more than forty percent of the average nominal labour related income. Nevertheless, political leaders and experts suggest the need to increase the accumulated tax burden in Lithuania. However, there may be a fundamental error in the fact that social insurance contributions and compulsory medical insurance contributions to funds are not counted in the tax burden of individuals and legal entities. Fortunately, last year's budget already considers social benefits as part of tax revenues. Unfortunately, in the continuity of the fiscal policy of Lithuania in the XXI century there is a small number of signs. Public finance and taxes are the very essential issue of the country's economic policy. Without a taxation any state cannot exist, therefore taxes are one of the utmost important component of state's fiscal policies. Taxes are the main source of a revenue for the national budget and when redistributed it generates the public expenditure. Because the government does not create a factual product the implementation of various functions of the state requires immense funds. Therefore, taxes are really important and significant source of the public finance revenue. Moreover, a problem could be the contrasting taxation inequality in Lithuania and in some other EU countries. Therefore, the equality of a tax burden can be an indicator for the public finance sustainability. The object of the publication is analysis of a possible taxation injustice in Lithuania. The aim of the publication is to imply a conception of a tax difference margin in the present-day's public finance. The main research methods that were used include scientific literature and public finance analysis, data collection and systematization, comparative statistical data analysis, graphical data representation, proportional analysis.
\end{abstract}

Keywords: Public Management; Public Finance; GDP-Tax Ratio; Sustainable Taxes

Reference to this paper should be made as follows: Dubauskas, G. 2019. A potential influence of tax inequality on the sustainable public management, Journal of Security and Sustainability Issues 8(4): 775-XX. http://doi.org/10.9770/jssi.2019.8.4(19)

JEL Classifications: H12, H63, E65 


\section{Introduction}

Finance and public spending management have a historical concept of the educational process and are one of the key economic and financial preparations in modern education. A fiscal entity is possible with a number of complex aspects, such as constant changes in the market economy, and the historical origin of money and monetary policy. Financial education could be related to the any undergraduate program (e.g. Senan 2018; Caplinska, Ohotina 2019). Moreover, a knowledge of the terminology related to budget and the taxation is familiar only for a minority of students. The purpose of this paper is to disclose the importance of financial management for students, including the public perception of the administrative and financial aspects of improper management of public revenues associated with the tax burden. The Lithuania's official average tax burden is usually more than thirty percent of the country's nominal gross domestic product in recent years (Table 1). Differently an average tax burden for private person is usually more than fifty percent from the average nominal labour related income. A certain difference apparently shows inequality in tax burden of legal and private persons. In other words that demonstrates unequal taxation concerning the capital income and the labour income. This inequality creates some tension and is likely to create even more.

Government finances and taxes are a very important issue of a country's economic policy. Without taxation, no state can exist; therefore, taxes are one of the most important components of the state budget policy. Taxes are the main source of income for the national budget, and when it is redistributed it generates government spending. Since the government does not create an actual product, the implementation of various functions of the state requires huge funds. Therefore, taxes are a truly important and significant source of revenue for public finances. Moreover, the problem may be a contrasting tax disparity in Lithuania and in some other EU countries. Therefore, equality of tax burden can be an indicator of the sustainability of public finances. The publication object is an analysis of possible tax injustice in Lithuania. The purpose of the publication is to introduce the concept of tax differentials in modern public finances. The main research methods used were the analysis of public finances in the legal and scientific literature, data collection and systematization, comparative statistical analysis of data, graphical presentation of data, proportional analysis.

Moreover the taxation policy can play an important role in reducing inequalities in the distribution of post-tax income. In addition, tax policy is a key to increase revenues for financing government spending on transfers, health and education that are conducive to low-income households as well as growth-friendly infrastructures that can also improve social justice (De Haan 2002). There is a lot of attention to related questions in the recent scientific literature (Diržyte et al. 2017; Luzgina 2017; Osipov et al. 2018; Vandina et al. 2018; Kosova et al. 2019).

Furthermore an intention of the paper is to reveal how taxation, public spending and fiscal policy could be perceived by taxpayers. In addition, it also attempts to answer the questions about the financial and economic importance on financial education. Additionally an idea of the article is to show a large difference concerning the tax burden for various layers of the society. The research methods and analysis used in the research were qualitative and quantitative research methods; the data was collected in the local department of statistics and in other financial institutions. Some empirical evidence was compiled from teaching public finance and from preparing research studies and textbooks.

Continuity and sustainability of public finances is currently a topic in the discussion of economic policy and public administration. However, this occurs as a result of the residual effects of the previous debt crises in Europe and the long-term pressure of government spending caused by obstructive demographic changes in more developed countries. This paper analyzes some of the conceptualizations that were used to assess the continuity of public finances in the case of Lithuania. In addition, hypothetical public finance revenues sustainability criteria was moderately overviewed. There is little agreement among economic experts about the exact theoretical standard of government financial continuity and, in particular, sustainability. It is desirable that each conceptualization for assessing continuity and sustainability uses its own personal, sometimes different, definitions. In this case, the strengths and weaknesses of each of the approaches are studied and conditionally 
equated to each other. It was found that each formulation has its own functions. Approaches should be considered as cumulative content. The availability of data and modeling resources, directions of analysis, and other casespecific limitations affect the relative quality of the approaches in different situations. Currently, the continuity and sustainability of public finances is a hot question in many modern countries. The uncertainty was raised by several reviewers and analysts of state-funded finances in Western countries, where these finances are the form of sustainable development. After the financial crisis of the first decade of the twenty-first century, the national debt of many countries has risen sharply due to the forced accumulation of various resources and savings aimed at the financial sector and a fully system economy. Ascending commitments integrated with long-term subjects, similar to modifications at the sociological level, affect the symmetry between the number of people in the workforce and the number of pensioners.

\section{Agenda of Tax Burden in the Public Administration}

The relationship between growth and inequality has long been an important issue for economists, and over the years several influential theories have emerged. But for most people, the problem comes down to this increasing inequality is good or bad for growth? Those who believe that this is good, or at least necessary, argue that it stimulates entrepreneurs and is a source of general investment for the economy. Those who believe that this is bad, argue that it may prevent poorer people from investing in their education and encouraging them to grab a larger piece of the economic pie without increasing it (Keely 2015).

The personal tax debate is quite common without the concept of personal tax burden. In economics, the tax field or tax burden is the effect of a particular tax on the distribution of economic wealth. The imposition of a tax drives a wedge between the price that consumers pay and the price that producers get for the product, which usually imposes an economic burden on both producers and consumers. The concept was brought to the attention of the French physiocrats, who argued that all taxes ultimately fell on landowners and at the expense of land rent. It is said that the tax burden falls on the group that ultimately bears or ultimately must pay tax. The key concept is that the level of tax burden or tax burden depends not on where the income is collected, but on the price elasticity of demand and the price elasticity of supply.

The theory of tax burden has a number of practical results. For example, in some countries, social security taxes are paid by the employee and by the employer in half. However, some economists believe that the employee bears almost the entire tax burden, because the employer transfers the tax in the form of lower wages. It is believed that the tax liability falls on the employee. However, with the same success it can be argued that in some cases the amount of tax falls on the employer. This is due to the fact that both the price elasticity of demand and the price elasticity of supply influence how the tax falls. Price controls, such as minimum wages, which set a minimum price level, and market distortions, such as subsidies or social benefits, also complicate the analysis.

There are many misconceptions regarding the importance of financial education programs in higher education institutions and other institutions. It is especially important that public finances understand their publicity in totalitarian times anyway, public finances were called "state finances" because understanding the tax burden was a rather minor issue for the dominant idea of creating a "new world, or at least national socialism." Unfortunately, these provisions often remain in the perception of some civil servants and even in the concepts of the new generation. At the same time, typical economic, financial and administrative State's strategic problems are almost always linked to corruption and the non-transparent situation in the public sector. Thus, as already mentioned, these situations are probably the most common events in the management of public finances. Therefore, finances and especially public financial literacy can be one of contributing to the perception of corruption by the state.

In general, the concept of public finance in the educational process begins with tax and budget concepts. Revenues from municipal taxes and the structure of the budget can be presented as a good example in which people could see the structure of government finances, and this should probably be the closest example for 
every citizen of another country. On the other hand, such an approach may be more suitable for second or third year students, especially for part-time or postgraduate studies. Most students come directly from high school undergraduate or undergraduate programs and, as a rule, are not familiar with the practice of independent living and self-payment. Even more difficult is the understanding of the state and national budgets or, on the other hand, the theoretical financing of private entrepreneurship. However, their financing is carried out at the expense of income from taxable and non-taxable income. From the point of view of financial education, this is more or less significant. At the same time, a person begins to understand the role of the state (and municipalities) in the economy. Then the admission to the functions of state regulation of the economy as a function of redistribution, social functions and control functions is materialized. Financial education is also important for understanding the structure of revenues and expenditures of the state and local governments, for the basic laws that provide the basis for tax collection and allocation of appointments.

Tax submissions are often complex. As with the same concept, "taxes and fees for the public sector did not directly receive anything but fees for specific services" (Brammer, Walker 2017). Thus, the confusion in terms is rather constant, which once again demonstrates the need for public finance literacy in all areas of the curriculum for students or cadets. The tax burden of an authorized Lithuanian is usually less than thirty percent of the nominal gross domestic product of a country in recent years. Nevertheless, political leaders and so-called experts constantly point out the need to increase the accumulated tax burden in Lithuania (Table 1). However, there may be a fundamental error in the fact that social insurance contributions and compulsory medical insurance contributions to funds are not counted in the tax burden of individuals and legal entities. Luckily, last year's budget already considers social benefits as part of tax revenues. Moreover, modern changes have eliminated these problems when the all social benefits were included in employee's wages before taxes.

\section{A Potential Taxation Inequality}

In the public economy there are several theories of taxation. Governments at all levels (national, regional and municipal) need to increase revenues from various sources to finance public sector spending. According to the benefit theory, the state should levy taxes from individuals in accordance with the benefits provided to them. The more benefits a person receives from the activities of the state, the more he must pay the state. This principle has been seriously criticized for the following reasons: i) If the state supports a certain relationship between the benefits provided and the benefits obtained. This will be against the basic principle of tax. The tax, as we know, is a compulsory contribution, which is paid to government agencies to cover government expenses and provide general benefits. In case of tax no direct payment. ii) most of the costs incurred by the stylus are for the general benefit of its citizens. It is impossible to estimate the benefit that a particular person enjoys every year. iii) if we apply this principle in practice, then the poor will have to pay the highest taxes, because they receive more benefits from state services. If we get more from the poor at the expense of taxes, this is contrary to the principle of justice. In the theory of the cost of services, some economists were of the opinion that if the state would charge the actual cost of the services provided by the population, it would satisfy the idea of justice or fairness in taxation. The principle of the cost of services, no doubt, can be applied to some extent in cases where the services are out of price and are fairly easy to identify, for example, postal, railway services, electricity supply, etc. But most of the expenses incurred by the state cannot be fixed for each person, because it cannot be precisely defined. For example, how can we measure the cost of the services of the police, the armed forces, the judiciary, etc., for different people. Dalton also rejected this theory on the grounds that there are no reciprocal conditions in the tax (Dalton 1962).

Ability to pay theory describes the most popular and generally accepted principle of justice or fairness in taxation is that citizens must pay taxes to the government in accordance with their ability to pay. It seems very reasonable and fair that taxes should be levied on the basis of the taxable capacity of the individual. For example, if the taxable ability of person $\mathrm{A}$ is greater than that of person $\mathrm{B}$, the first should be asked to pay more taxes than the last. It seems that if taxes are levied according to this principle, as stated above, equity can be achieved. But our difficulties do not end here. The fact is that when we put this theory into practice, our 
difficulties actually begin. The problem arises with the definition of solvency. Economists are not unanimous in what should be the exact measure of a person's ability or ability to pay. The main points of view put forward in this respect are the following: i) Ownership of property. Some economists believe that owning a property is a very good basis for measuring solvency. This idea is rightly rejected on the grounds that if a person earns a large income but does not spend on the purchase of any property, he will then avoid taxation. On the other hand, another person who receives income acquires property and will be subject to taxation. Is it not strange and unjustified that a person who receives a large income is exempt from taxes, and another person with a small income is heavily levied; (ii) Cost-based tax: Some economists also argue that the capability or ability to pay tax should be measured by the costs incurred by a person. The more expenses, the higher the tax should be, and vice versa. The point of view is unreasonable and unfair in all respects. A person who has a large family for support must spend more than a person who has a small family. If we make expenses. As a solvency test, a former person who is already burdened with a large number of dependents will have to "pay more taxes than the latter with a small family. So it is unjustified. iii) Income as a basis. Most economists believe that income should be the basis for measuring a person's financial condition (Saez 2011). This seems very fair, and simply if the income of one person is more than another, then the first should be asked to pay more for state support than the second. That is why in the modern tax system of the many countries are considered the best test for measuring the solvency of a person. However, the proportional principle satisfies the idea of justice in taxation some classical economists proposed the principle of proportionality in taxation (Mill 2006). These economists were of the opinion that if taxes were levied in proportion to the incomes of individuals, this would bring equal sacrifices. The modern economists, however, differ with this view. They assert that when income increases, the marginal utility of income decreases. The equality of sacrifice can only be achieved if the persons with high incomes are taxed at higher rates and those with low income at lower rates. They favour progressive system of taxation, in all modern tax systems.

Regrettably, there are a few signs in the attempts to decrease the tax burden inequality and to promote the continuity of Lithuania's fiscal policy (Table 2,3,4). Moreover, it could be stated that insufficient financial education led to the nowadays situation. A similar evaluation about Lithuania's fiscal policy efficiency and the fiscal policy sustainability could be applied. It is not possible to neglect that wealth taxes are medieval taxes when nobody even had thoughts about value added tax, about excise duties, about profit tax and even about income tax. Therefore an inequality in the tax burden increases. For better taxation in post emerging markets the positive tax administration also counts. New IT systems used in tax administration increasingly include tools such as advanced risk management mechanisms to identify potential missing revenues. Efforts to reduce inconsistencies in the coastal zone by increasing the efficiency of information exchange between tax authorities have gained a new impulse. Tax refugees, often rich, have fewer places to hide their money. These initiatives also support the international efforts of the IMF, OECD, UN and World Bank to help low-income countries to develop more efficient tax systems (Saez, et al. 2011). Formally about 30 percent of the GDP is redistributed in Lithuania through taxes when the EU average is 38 percent (Table 1). According to the authors calculations about 34 percent of the GDP is redistributed in Lithuania (Table 6 and 7). Although in Lithuania there are many different taxes, only a few huge taxes bring to the government the greatest profit. About 40 percent of the Lithuanian national budget is collected as value added tax. The tax rate is 21 percent and obviously it is added to the price. Twenty percent of the national budget is collected in personal income tax. This is deceptive, however, since most of the income tax goes to other budgets (municipal and social), some of them are even formally considered to be other taxes. The real burden is great - every employer must pay the state almost as much money as it pays to employees (that is, 40-50 percent of actual income tax). Although the nominally fixed income tax rate is actually progressive, since the non-taxable part gradually decreases as wages increase. Corporate income tax (known as profit tax) is 15 percent, with an additional 15 percent on most dividends paid to individuals (which means a 30 percent effective tax rate on dividends). Nevertheless revenues from the profit tax create only eight percent of the national budget proceeds. Excise duties constitute the third largest income for the state (about twenty percent). Fuel, electricity, tobacco and alcohol are subject to additional excise tax. For this reason, car fuel in Lithuania is almost twice as expensive as in the countries where are no excise duties (Tables $8,9,10$ ). Real estate tax is paid only by companies and property owners, which is considered expensive (from 0.3 to 3 percent of the market price per year). Land tax is paid by each owner (from 0.01 to 4 percent). 
Municipalities determine the actual percentage and the market value of the property. Moreover the official calculations of the national tax burden announced in the Eurostat publications (apparently based on data from the Lithuanian Department of Statistics) probably are decreased. According to authors calculations the average tax to GDP ratio could be 35 percent that is quite close to the EU average 38 percent (Table 6). The formal tax burden as the GDP-Tax ratio is about thirty percent from Lithuania's gross domestic product in the last years (see Table 1). Besides, the average tax burden for a private person could be defined as the Salary-Tax Ratio is usually more than fifty five percent from the monthly average salary (Table 9,10,11).

Table 1. Lithuania's Tax to GDP Ratio* (percent)

\begin{tabular}{|c|c|c|c|c|c|c|c|c|c|c|c|}
\hline Year & 2008 & 2009 & 2010 & 2011 & 2012 & 2013 & 2014 & 2015 & 2016 & 2017 & 2018 \\
\hline Tax to GDP Ratio & 30.1 & 30.6 & 28.7 & 27.6 & 27.3 & 27.3 & 27.9 & 29.4 & 30.1 & 29.9 & 30.1 \\
\hline
\end{tabular}

*Some components of Social insurance funds probably are not included in taxes.

Source: European Commission, ECB

Table 2. Lithuania's National Budget (mln Eur)

\begin{tabular}{|c|c|c|c|c|c|c|c|c|c|c|c|}
\hline Year & 2008 & 2009 & 2010 & 2011 & 2012 & 2013 & 2014 & 2015 & 2016 & 2017 & 2018 \\
\hline $\begin{array}{c}\text { National Budget } \\
\text { (mln.Eur) }\end{array}$ & 7696 & 7425 & 7588 & 7640 & 7459 & 7656 & 7829 & 8331 & 8686 & 9046 & 9560 \\
\hline
\end{tabular}

Source: Lithuania's Department of Statistics, 2009-2019

Table 3. Lithuania Social Insurance Fund's Budget - SoDra (mln Eur)

\begin{tabular}{|c|c|c|c|c|c|c|c|c|c|c|c|}
\hline Year & 2008 & 2009 & 2010 & 2011 & 2012 & 2013 & 2014 & 2015 & 2016 & 2017 & 2018 \\
\hline $\begin{array}{c}\text { SoDra Budget } \\
\text { (mln.Eur) }\end{array}$ & 3248 & 3289 & 3037 & 3217 & 3363 & 3252 & 3059 & 3285 & 3439 & 3793 & 4198 \\
\hline
\end{tabular}

Source: Lithuania SoDra Statistics, 2009-2019

Table 4. Lithuania's Compulsory Health Insurance Funds (CHIF) budget (mln Eur)

\begin{tabular}{|c|c|c|c|c|c|c|c|c|c|c|c|}
\hline Year & 2008 & 2009 & 2010 & 2011 & 2012 & 2013 & 2014 & 2015 & 2016 & 2017 & 2018 \\
\hline $\begin{array}{l}\text { CHIF Budget } \\
\text { (mln.Eur) }\end{array}$ & 1270 & 1270 & 1160 & 1207 & 1154 & 1193 & 1282 & 1382 & 1440 & 1574 & 1764 \\
\hline
\end{tabular}

Source: Lithuania's Department of Statistics, 2009-2019

Table 5. Lithuania's Annual GDP 2008-2018 (mln Eur)

\begin{tabular}{|c|c|c|c|c|c|c|c|c|c|c|c|}
\hline Year & 2008 & 2009 & 2010 & 2011 & 2012 & 2013 & 2014 & 2015 & 2016 & 2017 & 2018 \\
\hline $\begin{array}{l}\text { Lithuania's GDP } \\
\text { (mln.Eur) }\end{array}$ & 32696 & 26935 & 28028 & 31275 & 33348 & 34959 & 36568 & 37433 & 38849 & 42190 & 45113 \\
\hline
\end{tabular}

Source: Lithuania's Department of Statistics, 2009-2019 
Table 6. Lithuania's Tax to GDP Ratio with Included Social Insurance and Compulsory Health Insurance Funds (percent)

\begin{tabular}{|c|c|c|c|c|c|c|c|c|c|c|c|}
\hline Year & 2008 & 2009 & 2010 & 2011 & 2012 & 2013 & 2014 & 2015 & 2016 & 2017 & 2018 \\
\hline Tax to GDP Ratio & 37.3 & 44.5 & 42.0 & 38.6 & 35,9 & 34.6 & 33.3 & 34.7 & 34.9 & 34.2 & 34.4 \\
\hline
\end{tabular}

Source: Based on the author's calculation

Table 7. Lithuania's GDP per Capita in Actual Prices (Eur)

\begin{tabular}{|c|c|c|c|c|c|c|c|c|c|c|c|}
\hline Year & 2008 & 2009 & 2010 & 2011 & 2012 & 2013 & 2014 & 2015 & 2016 & 2017 & 2018 \\
\hline GDP per capita & 10223 & 8515 & 9049 & 10328 & 11161 & 11819 & 12470 & 12886 & 13545 & 14916 & 16103 \\
\hline
\end{tabular}

Source: Lithuania's Department of Statistics, 2009-2019

Table 8. Lithuania's Average Monthly Salary Before Taxes Brutto (Eur)

\begin{tabular}{|c|c|c|c|c|c|c|c|c|c|c|c|}
\hline Year & 2008 & 2009 & 2010 & 2011 & 2012 & 2013 & 2014 & 2015 & 2016 & 2017 & 2018 \\
\hline $\begin{array}{c}\text { Monthly Salary } \\
\text { (Eur) }\end{array}$ & 672 & 614 & 614 & 630 & 646 & 678 & 715 & 757 & 823 & 885 & 970 \\
\hline
\end{tabular}

Source: Lithuania's Department of Statistics, 2009-2019

Table 9. Lithuania's Average Monthly Salary After Taxes (Netto) without Social Insurance Tax paid by Employer (Eur)

\begin{tabular}{|c|c|c|c|c|c|c|c|c|c|c|c|}
\hline Year & 2008 & 2009 & 2010 & 2011 & 2012 & 2013 & 2014 & 2015 & 2016 & 2017 & 2018 \\
\hline $\begin{array}{c}\text { Monthly Salary } \\
\text { (Eur) }\end{array}$ & 514 & 477 & 478 & 489 & 501 & 524 & 554 & 589 & 637 & 691 & 752 \\
\hline
\end{tabular}

Source: Lithuania's Department of Statistics, 2009-2019

Table 10. Lithuania's Average Monthly Salary Tax Burden Including Social Insurance Tax paid by Employer (Eur)

\begin{tabular}{|c|c|c|c|c|c|c|c|c|c|c|c|}
\hline Year & 2008 & 2009 & 2010 & 2011 & 2012 & 2013 & 2014 & 2015 & 2016 & 2017 & 2018 \\
\hline $\begin{array}{l}\text { Monthly Employee and } \\
\text { Employer Tax Burden } \\
\text { (Eur) }\end{array}$ & 386 & 346 & 345 & 355 & 365 & 385 & 404 & 425 & 466 & 495 & 548 \\
\hline
\end{tabular}

Source: Author's Calculation

Table 11. Lithuania's Average Monthly Employee Income-Tax Ratio including Social Insurance Tax paid by Employer (percent)

\begin{tabular}{|c|c|c|c|c|c|c|c|c|c|c|c|}
\hline Year & 2008 & 2009 & 2010 & 2011 & 2012 & 2013 & 2014 & 2015 & 2016 & 2017 & 2018 \\
\hline $\begin{array}{c}\text { Monthly Average Salary-Tax } \\
\text { Ratio (percent) }\end{array}$ & 57.4 & 56.4 & 56.2 & 56.4 & 56.5 & 56.8 & 56.5 & 56.1 & 56.6 & 55.9 & 56.5 \\
\hline
\end{tabular}

Source: Author's Calculation

Presented data clearly testifies to the inequality of the general tax burden- that is closer to the legal persons and businesses - and private persons tax burden on their salary income. Obviously it demonstrates unequal taxation of income from capital and labor income. The injustice probably produces some tension and can produce even more. 


\section{Conclusions}

The fast growth of emerging economies in the last decades has brought hundreds of millions of people out of absolute poverty and reduced income inequality around the world as a whole. Concurrently, before the financial and economic crisis of the previous decade, the most economies had high growth rates. However, in the post emerging economies, not in the all regions, citizens have benefited equally in these years of the growth. In contrast, income distribution tends to become more unequal. Nonetheless taxation system did not help to decrease these inequalities in many cases. It is obvious that there is some need for a wider financial education and better understanding of public and private finance risks in the all levels of administration managers. Eventually a demand for advanced financial education with the idea on transparency in budget and taxation could be evident. The clearness of public spending and procurement and budgetary policy are essential issues for the each country. The formal Lithuania's tax burden also known as the GDP-Tax ratio is about thirty percent from the gross domestic product. However, the average tax burden for a private person could be defined as the income from salary and the taxes paid ratio. That is usually more than fifty five percent from the average salary. This difference indicates an inequality of the general tax burden (GDP-tax ratio) - that is closer to the legal persons and businesses - and private persons tax burden (salary-tax ratio) on their salary income. Evidently it demonstrates an unequal taxation on the income from capital and the labor income. Moreover it demonstrates a possible inequality of the tax burden for businesses and for private individuals. Obviously it demonstrates the unequal taxation on income from capital and income linked to labor relations. This inequality creates some tension and can create even more. Therefore the process of financial education and financial literacy has existent importance to the general civic education for improving the financial understanding and skills in the public sector. Very often, the best citizen participation in the governance of their country is the payment of taxes that are intended for the most important state functions. One way to determine the country's aggregated or consolidated taxes paid by natural and legal persons could be the tax burden rate. Moreover the public finance data often reflects the country's approach to the calculation of the tax burden in the former emerging markets government institutions. Therefore, understanding of the real tax burden should encourage citizen's insistence for the clarity of public attendants in their operations and taxation equality improving processes. That also could be an outstanding financial literacy method for the country's sustainability with greater involvement in fiscal politics movements. Tax policy can play an important role in reducing inequality in the distribution of income after tax. In addition, tax policies are crucial for increasing revenues to finance government spending on transfers, health care, and education, which tend to favor low-income households, as well as growth-enhancing infrastructure that can also improve social justice.

\section{References:}

Aarma, A. (2012). The Foreign Commercial Banks in the Baltic States: Aspects of the Financial Crisis Internationalization. European Journal of Business and Economics, Vol 5. http://dx.doi.org/10.12955/ejbe.v5i0.161.

Allen, R. and Tommasi, D (eds.) (2011) Managing Government Expenditure: A Reference Book for Transition Countries. Paris: OECD. SIGMA. [Access on the Internet]: www.worldbank.org/publicsector/pe/oecdpemhandbook.pdf

AMECO Database, Total Tax Revenue by Country (2014). OECD Economics Department Working Papers, Paris.

Andersen, T.M. (2010). Fiscal sustainability in the wake of the financial crisis. Nordic Economic Policy Review 71-110.

Biudžeto vykdymo ataskaitų rinkiniai Sodra. (2019). [Access on the Internet]: https://www.sodra.lt/biudzeto-vykdymo-ataskaiturinkiniai

Brammer, S., Walker, H. 2017. Sustainable Procurement Practices in the Public Sector: an International Comparative Study. [Access through Internet] http://www.bath.ac.uk/management/research/pdf/2017-16.pdf

Caplinska, A.; Ohotina, A. 2019. Analysis of financial literacy tendencies with young people, Entrepreneurship and Sustainability Issues 6(4): 6(4) 1736-1749. http://doi.org/10.9770/jesi.2019.6.4(13)

Communication from the Commission to the European Parliament, The European Economic and Social Committee and The Committee of the Regions. The EU Council, Brussels, 2014. 
Dalton, H. (2009). Principles Of Public Finance. Routledge, 2009.

Davig, T., Leeper, E.M., Walker, T.B. 2011. Inflation and the fiscal limit. European Economic Review 55: 31-47.

De Haan, J., Sturm, J. E., and B. Volkerink. 2002. How to measure the tax burden on labour, paper presented at the CESifo Conference on Measuring the Tax Burden on Labour and Capital, Venice, July, 2002.

Diržytė, A.; Rakauskienė, O.G.; Servetkienė, V. (2017) Evaluation of resilience impact on socio-economic inequality. Entrepreneurship and Sustainability Issues, 4(4): 489-501. http://doi.org/10.9770/jesi.2017.4.4(7)

Domar, E. (1944). The "Burden of the Debt" and the National Income. The American Economic Review, 34(4): 798-827

Dubauskas G. (2013). Theories of Economics and Finance. Vilnius. http://www.lka.lt/lt/moksline-veikla/leidiniai/leidiniu.../ekonomika. html

EU Commission Staff Working Document. Economic Review of the Financial Regulation Agenda. Brussels. 2016. Eurostat database. [Access through Internet]: http://epp.eurostat.ec.europa.eu

EU Commission Staff Working Document. Economic Review of the Financial Regulation Agenda. Brussels. 2018.

Eurostat Yearbook, (2018). [Access on the Internet]: http://ec.europa.eu/eurostat/publications/statistical-books/eurostat-yearbook

International Monetary Fund. (2016). World Economic Outlook: Tensions from the Two-Speed Recovery: Unemployment, Commodities, and Capital Flows (No. April, 2016).

Johansson A, Heady C, Arnold J., Brys B. and Vartia L. (2008). Tax and Economic Growth. OECD Economics Department Working Papers, No 620, OECD Publishing

Jurgutis V. (1995). The Basics of Financial Science. (Finansų mokslo pagrindai). Vilnius, 1995.

Keeley, B. (2015). How does income inequality affect our lives?, in Income Inequality: The Gap between Rich and Poor, OECD Publishing, Paris: https://doi.org/10.1787/9789264246010-6-en

Kosova, T., Steblianko, I., Slobodyanyuk, N., Doroshkevych, V. 2019. Tax security of national economic systems in globalization conditions, Journal of Security and Sustainability Issues 8(3): 493-505. https://doi.org/10.9770/jssi.2019.8.3(16)

Lithuania Government Debt to GDP. 2018. [Access through Internet]: https://tradingeconomics.com/lithuania/government-debt-to-gdp

Lithuania Proposes Income Tax Cuts to Boost Growth, New York Times, 2018, April 17. [Access through Internet] https://www.nytimes. com/reuters/2018/04/17/business/17reuters-lithuania-tax.html

Luzgina, A. (2017). Problems of corruption and tax evasion in construction sector in Belarus. Entrepreneurship and Sustainability Issues, 5(2): 263-282. http://doi.org/10.9770/jesi.2017.5.2(8)

Madsen Pirie, Think Tank. (2012) A Story of the Adam Smith Institute, Biteback Publishing, 2012.

Mill, John Stuart. (2006). On Liberty. Penguin Classics ISBN 978-0141441474

Ministry of Finance of Lithuania. (2017). [Access through Internet]: http://finmin.lrv.lt/lt/aktualus-valstybes-finansu-duomenys/ valstybes-biudzeto-ir-savivaldybiu-biudzetu-vykdymo-duomenys.

OECD, (2014). Total Tax Revenue by Country, Economics Department Working Papers, Paris, 2014.

Osipov, G.V., Glotov, V.I., Karepova, S.G. (2018). Population in the shadow market: petty corruption and unpaid taxes. Entrepreneurship and Sustainability Issues, 6(2): 692-710. http://doi.org/10.9770/jesi.2018.6.2(16)

Procurement Management (2017). [Access on the Internet]: https://www.deltabid.com/procurement-management/

Saez, Emanuel, Joel Slemrod and Seth Giertz (2011). The elasticity of taxable income with respect to marginal rates: A critical review, in Journal of Economic Literature, American Economic Association, 50 (1).

Schiavo-Campo, S. and Tommasi, D. (1999). Managing Government Expenditure. Manila: ADB. [Access on the Internet]: www.adb. org/documents/manuals/govt_expenditure/

Senan, N.A.M. 2018. Developmental review program impact on enhancing the effectiveness of "Teaching and Learning" in accounting 
program: a case study in a Saudi University, Entrepreneurship and Sustainability Issues 6(2): 1001-1017. http://doi.org/10.9770/ jesi.2018.6.2(35)

Shah, A. (ed.) (2013). Budgeting and Budgetary Institutions. Washington, DC: World Bank. [Access on the Internet]: http://siteresources. worldbank.org/PSGLP/Resources/BudgetingandBudgetaryInstitutions.pdf

Tax Burden for Typical Workers in the EU. 2014. New Direction - The Foundation for European Reform, Bruxelles, Belgium

Tax Revenue as Percentage of GDP by Country. The World Bank Report, 2015. [Access via the Internet]: http://data.worldbank.org/ indicator/gc.tax.totl.gd.zs?page $=1$

Taxation trends in the European Union, Data for the EU Member States, Iceland and Norway. Eurostat Statistical book. 2014.

The Case for Financial Literacy in Developing Countries. (2014). The International Bank for Reconstruction and Development, Washington, DC

Vandina, O., Mkrtychan, Z., Denisov, I., Vechkinzova, Y. (2018). The tax mechanism of managing the process of formation of information economy in modern Russia. Entrepreneurship and Sustainability Issues, 6(2): 830-839. https://doi.org/10.9770/jesi.2018.6.2(24) 